\title{
EFFECTIVENESS OF SEDIMENTATION PONDS IN FOREST DRAINAGE SYSTEMS IN HEAVY RAIN PERIODS
}

\author{
Jānis Kalniņšš , Guna Petaja² \\ ${ }^{1}$ Latvia University of Life Sciences and Technologies, Latvia \\ ${ }^{2}$ Latvian State Forest Research Institue ‘Silava’, Latvia \\ j.kalnins7@gmail.com
}

\begin{abstract}
Establishment of sedimentation ponds is a method to reduce the negative impact of forest management (fellings, drainage) on the quality of nearby rivers, lakes and streams. The aim of the study was to determine the efficiency of sedimentation ponds in forest drainage systems during high precipitation periods. Nine sedimentation ponds with different drainage areas were analyzed. The sedimentation ponds are located in the northern part of Latvia on different types of soils and managed by the Joint Stock Company 'Latvia's State Forests'. In order to determine efficiency of these ponds the following parameters in water samples were measured: nitrate $\left(\mathrm{NO}_{3}{ }^{-}\right)$, ammonium $\left(\mathrm{NH}_{4}^{+}\right)$, phosphate ion $\left(\mathrm{PO}_{4}^{3-}\right)$, total nitrogen and total suspended solid concentration. The amount of precipitation was taken into account. Results show that there is a correlation between the amount of precipitation and concentrations of total suspended solids and total nitrogen. Ammonium ion concentration was the only parameter that significantly exceeded waterquality standards in Latvia. Only one of the objects had high concentration of pollutants, which could be explained with the peaty soil of its drainage area. In further studies data should be collected more frequently, three or four days during one precipitation period.
\end{abstract}

Key words: sedimentation pond, nitrate, ammonium, phosphate, total nitrogen, total suspended solids.

\section{Introduction}

After periods of heavy rain a large amount of runoff water infiltrates into groundwater. While water is moving through soil, it disturbs and absorbs particles of organic and inorganic compounds. A large portion of this water finds its way to drainage system, if the forest is drained and then flows into the rivers and further in seas. Biogenic elements and suspended solids have a negative effect on water quality. Most of these particles are harmful to fish and other aquatic wildlife, and induce growth of Chlorophyta and Cyanophyta, which produce toxins (Campanella et al., 2001). The task of sedimentation ponds is to collect and to detain the flow of suspended particles and biogenic elements from forest drainage systems and to protect the quality of nearby water bodies. Increased availability of phosphate ions (exceeding $0.5 \mathrm{mg} \mathrm{L}^{-1}$ ) and sufficient amount of nitrogen promote excessive plant growth. The concentration of nitrates in pure drainage systems is $0.4-8 \mathrm{mg} \mathrm{L}^{-1}$, while contaminated - up to $50 \mathrm{mg} \mathrm{L}^{-1}$ (Klaviňš, 1995). If concentrations of both types of ions in water samples collected from a sedimentation pond do not exceed the limit values, the pond can be considered as effective.

The size of incoming particles is very important for the sedimentation pond to work efficiently. If the size of suspended particles is small, such as unbound ions, their deposition will not occur so quickly and they can reach the further watercourse. If the size of these particles is large and the water flow in the sedimentation pool is very small, most pollutants will be detained (Kløve, 2000). Properly constructed sedimentation ponds can hold up to $90 \%$ of suspended particles (Joensuu, Ahti, \& Vuollekoski, 1999). Soil type and vegetation also play an important role in deposition efficiency. In most studies, the efficiency of phosphorus accumulation the buffer zone is calculated from the total input and output of total phosphorus or the concentration of water between the sections with or without sedimentation pond (Väänänen, 2008). After cleaning drainage systems, ditches are unstable and minerals are often washed out. Heavy mineral particles deposit in the sedimentation pond, thus reducing the depth and area for deposition of biogenic and solid suspended matter (Joensuu, 1997). Sedimentation ponds should be cleaned regularly to make them work more efficiently.

Over the last 20 years extensive studies have been carried out on sedimentation ponds in various nutrient rich soils, but there are not many extensive reports about heavy rainfall influence on sedimentation efficiency. Based on the analysis of the existing situation, the aim of this study is to determine the efficiency of sedimentation basins in forest drainage systems during rainy periods and to analyze them.

\section{Materials and Methods}

Sedimentation ponds were selected according to the information from archived projects of the Joint Stock Company 'Latvia's State Forests' about forest drainage systems. This company was chosen because their sedimentation ponds are constructed by united design and are managed regularly. The projects chosen were not older than three years. The selected objects were surveyed in order to determine, if they are not dammed and contain water. In some objects the water level was high all season but some ponds were almost empty. Drainage basin area, soil properties, and distance to a river or stream also varied between the objects. From the 15 initially chosen objects only 9 
were suitable for this research. The first two objects are located in Ērgḷi municipality, Jumurda parish, Piebalga forest compartment, forest drainage system 'Ilzites'. The first sedimentation pond is located on the magistral ditch M-125. Its distance to estuary is $130 \mathrm{~m}$ and its area of drainage basin -190 ha. The second pond is located on the magistral ditch $\mathrm{N}-120$. Its distance to estuary is $20 \mathrm{~m}$ and the size of drainage basin area 50 ha. The third, fourth and fifth sedimentation pond are located in Mazsalaca municipality, Ramata parish, Rūjiena forest compartment, forest drainage system 'Kerzas masīvs'. The ponds are located on magistral ditches N-29, N-85 and N-75; their distance to estuary is $30 \mathrm{~m}, 20 \mathrm{~m}$ and $20 \mathrm{~m}$ and drainage basin area 15 ha, 30 ha and 20 ha, accordingly. The objects 6, 7 and 8 are located in Limbaži municipality, Pāle parish, Limbaži forest compartment, forest drainage system 'Lācīšu mežs'. The ponds are located on magistral ditches $\mathrm{N}-11, \mathrm{~N}-9$ and $\mathrm{N}-2$, their distance to estuary is $2 \mathrm{~m}, 5 \mathrm{~m}$ and $15 \mathrm{~m}$ and drainage basin area - 24 ha, 10 ha and 15 ha, accordingly. The final object is located in Salacgrīva municipality, Salacgrīva parish, Salacgrīva forest compartment, forest drainage system 'Zonepes masīvs'. The pond is located on magistral ditch N-60, its distance to estuary is $71 \mathrm{~m}$ and drainage basin area is 1235 ha.

In each object two sample plots were established before and after the sedimentation pond. Samples were collected three times during heavy rain periods, transferring 750-1000 ml of water to clean plastic bottles and transporting the bottles to the laboratory in an air-conditioned container. Water was collected from downstream first, ensuring that water samples do not contain additional sediments. Concentrations of the main pollutants - nitrate $\left(\mathrm{NO}_{3}^{-}\right)$, ammonium $\left(\mathrm{NH}_{4}^{+}\right)$, phosphate ions $\left(\mathrm{PO}_{4}^{3-}\right)$ total nitrogen and total suspended solids - were measured. Ammonium ion concentration in water samples was determined spectrophotometrically according to LVS ISO 7150/1:1984 standard. Nitrate ion concentration was measured using Machenery Nagel PF11 photometer and nitrate testing set Visocolor ECO 5-41. Phosphate ion concentration was determined according to LVS EN ISO 6878 standard using ammonium molibdate spectrophotometric method. Total nitrogen content was assessed using modified Kjeldahl method. Concentration of total suspended solids was determined according to LVS EN 1484:2000 standard using catalytic burning and infrared detection (Lībiete-Zālīte, 2012). Data obtained in this study were analyzed according to water-quality requirements in Latvia (Cabinet of Ministers of the Republic of Latvia, 2002). In total, 54 samples were collected and analyzed.

The amount of precipitation was determined during sample collection and three days before it. Precipitation was determined from archived data in weather measurement stations in the studied region and published in windguru.cz. Mostly this long rain period was chosen because of infiltration rate. Rainwater infiltration is increasing and more biogenic elements are eroded from soil when precipitation is higher for a longer period of time (Holden \& Burt, 2002). That is due to soil water bearing capacity and threshold, when the soil is wet, it can absorb more water but when it is dry, it repels water, for example, sandy soil (Wu \& Gschwend, 1986).

To determine if analyzed sedimentation pond works efficiently or works at all, the concentrations of all pollutants should be compared with those given in water quality standard for drinking and fish water in Latvia (table 1).

\section{Results and Discussion}

There is no direct data correlation between sedimentation ponds due to their differences in workload and properties of drained areas. One of the main factors that affected accuracy of results was infrequent data collection. The lowest nitrate concentration determined was $0 \mathrm{mg} \mathrm{L}^{-1}$, but the highest $-0.98 \mathrm{mg} \mathrm{L}^{-1}$. According to the results, $88 \%$ of the analyzed samples

\section{Water quality standard for drinking and fish waters in Latvia}

Table 1

\begin{tabular}{|l|c|c|c|}
\hline \multicolumn{1}{|c|}{ Parameter } & Unit of measurement & Good quality concentration & Marginal concentration \\
\hline Nitrate ions & $\mathrm{mg} \mathrm{L}^{-1}$ & 25 & 50 \\
\hline Phosphate ions & $\mathrm{mg} \mathrm{L}^{-1}$ & 0,18 & 3 \\
\hline Total nitrogen & $\mathrm{mg} \mathrm{L}^{-1}$ & 1 & 0.3 \\
\hline Ammonium ions & $\mathrm{mg} \mathrm{L}^{-1}$ & 0.03 & - \\
\hline Total suspended solids & $\mathrm{mg} \mathrm{L}^{-1}$ & 25 & 3 \\
\hline
\end{tabular}


Element concentrations in sedimentation pond in forest drainage system 'Ilzītes' on ditch N-120

\begin{tabular}{|l|c|c|c|c|}
\hline \multirow{2}{*}{ Elements in water samples } & \multirow{2}{*}{\begin{tabular}{c} 
Sample plot $\begin{array}{c}\text { Before/after sedimentation } \\
\text { pond) }\end{array}$ \\
\cline { 2 - 5 }
\end{tabular}} & \multicolumn{3}{|c|}{$\begin{array}{c}\text { Concentration depending on precipitation, } \\
\mathrm{mg} \mathrm{L}^{-1}\end{array}$} \\
\cline { 2 - 5 } phosphate ions & before & 0 & 0.02 & 0.03 \\
\cline { 2 - 5 } & after & 0 & 0.01 & 0.02 \\
\hline \multirow{2}{*}{ nitrate ions } & before & 0.51 & 0.98 & 0.85 \\
\hline \multirow{2}{*}{ total nitrogen } & after & 1.87 & 2.96 & 2.85 \\
\hline \multirow{2}{*}{ ammonium ions } & before & 1.45 & 1.20 & 2.74 \\
\hline \multirow{2}{*}{ total suspended solids } & after & 0.06 & 0.14 & 0.02 \\
\cline { 2 - 5 } & before & 0.03 & 0.03 & 0.02 \\
\cline { 2 - 5 } & after & 8.00 & 8.00 & 6.00 \\
\hline
\end{tabular}

had good water quality even in the heaviest rain period. The lowest phosphate concentration was $0 \mathrm{mg} \mathrm{L}^{-1}$ but the highest $-0.03 \mathrm{mg} \mathrm{L}^{-1}$. The lowest ammonium ion concentration was $0 \mathrm{mg} \mathrm{L}^{-1}$ but the highest $0.26 \mathrm{mg} \mathrm{L}^{-1}$. The lowest total nitrogen concentration was $0.21 \mathrm{mg} \mathrm{L}^{-1}$ but the highest $-2.96 \mathrm{mg} \mathrm{L}^{-1}$. The lowest concentration of total suspended solids was $0 \mathrm{mg} \mathrm{\textrm {L } ^ { - 1 }}$ but the highest $-1409 \mathrm{mg} \mathrm{L}^{-1}$. In the water quality requirements of Latvia, it is mentioned that on high flow periods, such as heavy rainfall or floods, it is acceptable that total suspended solid runoff is higher than the limit concentration allows.

In the first object, located in the forest drainage system 'Ilzites' on ditch $\mathrm{N}-120$, when precipitation was the lowest, only the concentration of ammonium ions exceeded the limit concentration by $0.1 \mathrm{mg} \mathrm{L}^{-1}$ (Table 2). However, this concentration decreased by $50 \%$ after the sedimentation pond, while nitrate ion concentration decreased by $15 \%$, total nitrogen concentration - by $22 \%$ and total suspended solids by $63 \%$. No phosphates were detected in the samples. When the amount of precipitation in the past 3 days was $12.2 \mathrm{~mm}$, none of the parameters exceeded limit concentrations. In the period with the highest precipitation, ammonium concentration increased, but still did not exceed the limit concentration and decreased by $79 \%$ after the sedimentation pond. The possible explanation for the low concentrations could be mixing of water between pond and river.

The second sedimentation pond was located in the same drainage system, but on the main ditch M-125 (Table 3). Results show that concentration of some elements increased after the sedimentation pond. It could be related to high water speed after the

Table 3

Element concentrations in sedimentation pond in forest drainage system 'Ilzītes' on ditch M-125

\begin{tabular}{|l|c|c|c|c|}
\hline \multirow{2}{*}{$\begin{array}{c}\text { Elements in water } \\
\text { samples }\end{array}$} & \multirow{2}{*}{$\begin{array}{c}\text { Sample plot (Before/after sedimentation pond) } \\
\text { phosphate ions }\end{array}$} & \multicolumn{3}{|c|}{$\begin{array}{c}\text { Concentration depending on } \\
\text { precipitation, } \mathrm{mg} \mathrm{L}^{-1}\end{array}$} \\
\cline { 2 - 5 } & before & $3 \mathrm{~mm}$ & $14.9 \mathrm{~mm}$ & $12.20 \mathrm{~mm}$ \\
\cline { 2 - 5 } & after & 0.00 & 0.00 & 0.03 \\
\hline \multirow{2}{*}{ nitrate ions } & before & 0.00 & 0.01 & 0.02 \\
\hline \multirow{2}{*}{ total nitrogen } & after & 0.25 & 0.38 & 0.30 \\
\hline \multirow{2}{*}{ ammonium ions } & before & 1.26 & 1.54 & 1.41 \\
\cline { 2 - 5 } & after & 1.45 & 1.20 & 2.74 \\
\hline \multirow{2}{*}{ total suspended solids } & before & 0.10 & 0.04 & 0.01 \\
\cline { 2 - 5 } & after & 0.11 & 0.06 & 0.01 \\
\hline
\end{tabular}


Element concentrations in sedimentation pond in forest drainage system 'Lācīšu mežs' on ditch N-2

\begin{tabular}{|l|c|c|c|c|}
\hline \multirow{2}{*}{ Elements in water samples } & \multirow{2}{*}{ Sample plot (Before/after sedimentation pond) } & \multicolumn{3}{|c|}{$\begin{array}{c}\text { Concentration depending on } \\
\text { precipitation, } \mathrm{mg} \mathrm{L}^{-1}\end{array}$} \\
\cline { 2 - 5 } & & $2.4 \mathrm{~mm}$ & $14 \mathrm{~mm}$ & $12.3 \mathrm{~mm}$ \\
\hline \multirow{2}{*}{ phosphate ions } & before & 0.00 & 0.00 & 0.01 \\
\hline \multirow{2}{*}{ nitrate ions } & after & 0.00 & 0.01 & 0.01 \\
\hline \multirow{2}{*}{ total nitrogen } & before & 0.00 & 0.30 & 0.00 \\
\hline \multirow{2}{*}{ ammonium ions } & after & 0.00 & 0.31 & 0.00 \\
\hline \multirow{2}{*}{ total suspended solids } & before & 0.28 & 0.54 & 0.32 \\
\cline { 2 - 5 } & after & 0.21 & 0.59 & 0.35 \\
\cline { 2 - 5 } & before & 0.04 & 0.00 & 0.01 \\
\cline { 2 - 5 } & after & 0.00 & 0.01 & 0.01 \\
\hline
\end{tabular}

pond, raising up sediments from low flow periods. In the lowest rainfall period, all the parameters did not change significantly after the pond, except for total suspended solids, which increased by $43 \%$. Ammonium concentration is the only variable that lowers water quality according to the standard. In the second highest rainfall period, all the concentrations were higher than before except for ammonium ions. The concentration of phosphate ions decreased by $33 \%$, nitrate ions - by $23 \%$ and total suspended solids - by $25 \%$. When precipitation was the highest, nitrates, total nitrogen and total suspended solids had even higher output, for example, the concentration of total suspended solids increased 4 times. Ammonium ions also were present and increased by $50 \%$. This sedimentation pond can be considered inefficient, as some of the concentrations increased, however none of them exceeded the limit values.
The amount of precipitation did not differ between the rest of objects. All the parameters of the object located in 'Lācīšu mežs' ditch N-2 were within the range of water-quality requirements, except for the concentration of total suspended solids that increased even more after the sedimentation pond (Table 4). The possible explanation could be another magistral ditch that flows towards this ditch and corners just before the sedimentation pond, thereby mixing waters. In the period of low precipitation, the total nitrogen concentration significantly decreased after the sedimentation pond. Within periods of higher precipitation only the total nitrogen concentration decreased significantly after the sedimentation pond.

Results from the ditch N-9 show that in the period of low rainfall the concentration of total suspended solids exceeded the limit value, but significantly decreased after the sedimentation pond (Table 5). The

Table 5

Element concentrations in sedimentation pond in forest drainage system 'Lācīšu mežs' on ditch N-9

\begin{tabular}{|l|c|c|c|c|}
\hline \multirow{3}{*}{ Elements in water samples } & \multirow{2}{*}{$\begin{array}{c}\text { Sample plot (Before/after sedimentation } \\
\text { pond) }\end{array}$} & \multicolumn{3}{|c|}{$\begin{array}{c}\text { Concentration depending on } \\
\text { precipitation, } \mathrm{mg} \mathrm{L}^{-1}\end{array}$} \\
\cline { 2 - 5 } & & $2.4 \mathrm{~mm}$ & $14 \mathrm{~mm}$ & $12.3 \mathrm{~mm}$ \\
\hline \multirow{2}{*}{ phosphate ions } & before & 0.02 & 0.01 & 0.02 \\
\hline \multirow{2}{*}{ nitrate ions } & after & 0.01 & 0.01 & 0.03 \\
\hline \multirow{2}{*}{ total nitrogen } & before & 0.00 & 1.24 & 1.12 \\
\hline \multirow{2}{*}{ ammonium ions } & after & 0.00 & 1.22 & 0.88 \\
\hline \multirow{2}{*}{ total suspended solids } & before & 0.30 & 1.67 & 2.10 \\
\cline { 2 - 5 } & after & 0.33 & 1.61 & 1.81 \\
\cline { 2 - 5 } & before & 0.03 & 0.01 & 0.02 \\
\cline { 2 - 5 } & after & 0.01 & 0.02 & 0.05 \\
\hline
\end{tabular}


Table 6

Element concentrations in sedimentation pond in forest drainage system 'Lācǐšu mežs' on ditch N-11

\begin{tabular}{|l|c|c|c|c|}
\hline \multirow{2}{*}{ Elements in water samples } & \multirow{2}{*}{$\begin{array}{c}\text { Sample plot (Before/after sedimentation } \\
\text { pond) }\end{array}$} & \multicolumn{3}{|c|}{$\begin{array}{c}\text { Concentration depending on } \\
\text { precipitation, } \mathrm{mg} \mathrm{L}^{-1}\end{array}$} \\
\cline { 2 - 5 } & & $2.4 \mathrm{~mm}$ & $14 \mathrm{~mm}$ & $12.3 \mathrm{~mm}$ \\
\hline \multirow{2}{*}{ phosphate ions } & before & 0.01 & 0.01 & 0.02 \\
\hline \multirow{2}{*}{ nitrate ions } & after & 0.02 & 0.02 & 0.02 \\
\hline \multirow{2}{*}{ total nitrogen } & before & 0.00 & 0.33 & 0.06 \\
\hline \multirow{2}{*}{ ammonium ions } & after & 0.00 & 0.34 & 0.04 \\
\cline { 2 - 5 } & before & 0.31 & 0.76 & 0.81 \\
\hline \multirow{2}{*}{ total suspended solids } & after & 0.29 & 0.79 & 0.80 \\
\cline { 2 - 5 } & before & 0.26 & 0.02 & 0.01 \\
\cline { 2 - 5 } & after & 81.00 & 62.00 & 4.00 \\
\cline { 2 - 5 } & before & 80.00 & 59.00 & 7.00 \\
\hline
\end{tabular}

concentration of ammonium ions decreased by $67 \%$ and that of phosphate ions - by $50 \%$. In the highest flow period, the concentration of total suspended solids did not decrease below the limit value. The concentration of total nitrogen increased along with higher rainfall (from 0.33 to $1.81 \mathrm{mg} \mathrm{L}^{-1}$ ).

Results from the ditch $\mathrm{N}-11$ show that the total nitrogen concentration increased along with increased amount of precipitation. The concentration of total suspended solids decreased during periods with high amount of precipitation - from 80 to $7 \mathrm{mg} \mathrm{L}^{-1}$ (Table 6). When precipitation was the lowest, ammonium ion concentration was the highest and exceeded the limit value of the water-quality standard; however, the sedimentation pond decreased this concentration by $92 \%$.

Results from the ditch N-29 (table 7) in the forest drainage system 'Kerzas masivvs' show that concentrations of ammonium ions and total suspended solids exceed limit values. Concentrations of total suspended solids and total nitrogen were the highest when precipitation was the highest. The concentration of ammonium ions increased after the sedimentation pond, exceeding the limit concentration by $0.3 \mathrm{mg} \mathrm{L}^{-1}$ (Table 7).

There were no significant differences between parameters of the pond located on ditch N-75 in all three rainfall periods. When precipitation was the lowest, the concentration of total suspended solids increased by $118 \%$ after the sedimentation pond exceeding the water-quality standard value. This could be explained with contamination of inorganic matter from landslides before the pond. The lowest concentrations after the sedimentation pond were detected, when precipitation was $12.3 \mathrm{~mm}$ (Table 8).

Table 7

Element concentrations in sedimentation pond in forest drainage system 'Kerzas masīvs' on ditch N-29

\begin{tabular}{|l|c|c|c|c|}
\hline \multirow{2}{*}{ Elements in water samples } & Sample plot (Before/after sedimentation & \multicolumn{3}{|c|}{$\begin{array}{c}\text { Concentration depending on } \\
\text { precipitation, } \mathrm{mg} \mathrm{L}^{-1}\end{array}$} \\
\cline { 2 - 5 } & & $2.4 \mathrm{~mm}$ & $14 \mathrm{~mm}$ & $12.3 \mathrm{~mm}$ \\
\hline \multirow{2}{*}{ phosphate ions } & before & 0.01 & 0.00 & 0.01 \\
\hline \multirow{2}{*}{ nitrate ions } & after & 0.00 & 0.00 & 0.01 \\
\hline \multirow{2}{*}{ total nitrogen } & before & 0.08 & 0.16 & 0.00 \\
\hline \multirow{2}{*}{ ammonium ions } & after & 0.04 & 0.21 & 0 \\
\hline \multirow{2}{*}{ total suspended solids } & before & 0.44 & 0.54 & 0.73 \\
\cline { 2 - 5 } & after & 0.49 & 0.55 & 0.71 \\
\cline { 2 - 5 } & before & 0.06 & 0.01 & 0.00 \\
\hline
\end{tabular}


Element concentrations in sedimentation pond in forest drainage system 'Kerzas masīvs' on ditch N-75

\begin{tabular}{|l|c|c|c|c|}
\hline \multirow{3}{*}{ Elements in water samples } & \multirow{2}{*}{$\begin{array}{c}\text { Sample plot (Before/after sedimentation } \\
\text { pond) }\end{array}$} & \multicolumn{3}{|c|}{$\begin{array}{c}\text { Concentration depending on } \\
\text { precipitation, } \mathrm{mg} \mathrm{L}^{-1}\end{array}$} \\
\cline { 2 - 5 } & & $2.4 \mathrm{~mm}$ & $14 \mathrm{~mm}$ & $12.3 \mathrm{~mm}$ \\
\hline \multirow{2}{*}{ phosphate ions } & before & 0.01 & 0.00 & 0.01 \\
\cline { 2 - 5 } & after & 0.01 & 0.01 & 0.01 \\
\hline \multirow{2}{*}{ nitrate ions } & before & 0.00 & 0.00 & 0.00 \\
\hline \multirow{2}{*}{ total nitrogen } & after & 0.00 & 0.00 & 0.00 \\
\hline \multirow{2}{*}{ ammonium ions } & before & 0.44 & 0.42 & 0.43 \\
\hline \multirow{2}{*}{ total suspended solids } & after & 0.46 & 0.43 & 0.35 \\
\cline { 2 - 5 } & before & 0.00 & 0.00 & 0.01 \\
\cline { 2 - 5 } & after & 37.00 & 0.02 & 0.00 \\
\cline { 2 - 5 } & before & 11.00 & 0.00 \\
\hline
\end{tabular}

Table 9

Element concentrations in sedimentation pond in forest drainage system 'Kerzas masīvs' on ditch N-85

\begin{tabular}{|l|c|c|c|c|}
\hline \multirow{2}{*}{ Elements in water samples } & \multirow{2}{*}{\begin{tabular}{c} 
Sample plot $\begin{array}{c}\text { Before/after sedimentation } \\
\text { pond) }\end{array}$ \\
\cline { 2 - 5 }
\end{tabular}} & \multicolumn{3}{|c|}{$\begin{array}{l}\text { Concentration depending on precipitation, } \\
\text { mg L }\end{array}$} \\
\cline { 2 - 5 } phosphate ions & before & $2.4 \mathrm{~mm}$ & $14 \mathrm{~mm}$ & $12.3 \mathrm{~mm}$ \\
\cline { 2 - 5 } & after & 0.00 & 0.02 & 0.03 \\
\hline \multirow{2}{*}{ nitrate ions } & before & 0.00 & 0.00 & 0.01 \\
\hline \multirow{2}{*}{ total nitrogen } & after & 0.06 & 0.77 & 0.38 \\
\hline \multirow{2}{*}{ ammonium ions } & before & 0.93 & 1.54 & 1.30 \\
\hline \multirow{2}{*}{ total suspended solids } & after & 0.82 & 1.57 & 1.26 \\
\cline { 2 - 5 } & before & 0.06 & 0.02 & 0.09 \\
\cline { 2 - 5 } & after & 19.00 & 1409.00 & 0.01 \\
\hline
\end{tabular}

Element concentrations in sedimentation pond in forest drainage system

Table 10 'Zonepes masīvs' on ditch N-60

\begin{tabular}{|l|c|c|c|c|}
\hline \multirow{2}{*}{ Elements in water samples } & \multirow{2}{*}{$\begin{array}{c}\text { Sample plot (Before/after sedimentation } \\
\text { pond) }\end{array}$} & \multicolumn{3}{|c|}{ Concentration depending on precipitation, } \\
\cline { 3 - 5 } & & $2.4 \mathrm{~mm}$ & $14 \mathrm{~mm}$ & $12.3 \mathrm{~mm}$ \\
\hline \multirow{2}{*}{ phosphate ions } & before & 0.00 & 0.01 & 0.02 \\
\hline \multirow{2}{*}{ nitrate ions } & after & 0.01 & 0.01 & 0.03 \\
\hline \multirow{2}{*}{ total nitrogen } & before & 0.02 & 0.00 & 0.09 \\
\hline \multirow{2}{*}{ ammonium ions } & after & 0.05 & 0.00 & 0.12 \\
\cline { 2 - 5 } & before & 0.40 & 0.63 & 1.06 \\
\hline \multirow{2}{*}{ total suspended solids } & after & 0.43 & 0.55 & 1.06 \\
\cline { 2 - 5 } & before & 0.06 & 0.01 & 0.01 \\
\cline { 2 - 5 } & after & 0.06 & 0.02 & 0.01 \\
\hline
\end{tabular}


Results from the pond on the ditch N-85 show that in the period with the highest precipitation level the concentrations of suspended solids, nitrate ions and total nitrogen were the highest, but after the sedimentation pond only the concentration of total suspended solids was reduced (by $68 \%$ and still exceeding the limit concentration). This could be explained with the fact that before the sedimentation pond there was a landslide from water erosion, thus increasing the total sediment content. Ammonium ion concentration was the highest in the first and the last period of precipitation, but after the sedimentation pond concentrations decreased below the limit value (Table 9).

The water level in the sedimentation pond located in the forest drainage system 'Zonepes masīvs' on ditch N-60, was high in all periods of precipitation. The concentration of total suspended solids in the highest and the lowest precipitation period exceeded the limit value and in the first period ammonium ion concentration exceeded the limit concentration as well. In the last period, the total nitrogen concentration was the highest. Concentrations of phosphate and nitrate ions and the total suspended solid content increased after the sedimentation pond. The highest concentrations of total nitrogen, nitrate and phosphate ions were detected in the last period (Table 10). Results may be influenced by the time of water runoff and infiltration, because the drainage area is higher than in all other objects.

\section{Conclusions}

1. In most of the objects total suspended solid and ammonium ion concentration exceeded the limit values of the water quality standard in Latvia, which directs on poor sedimentation pond structure and poor efficiency. Total suspended solids attract light, increasing water temperature and reducing water capability to dissolve oxygen, which leads to fish suffocation. The highest total suspended solid concentration was $447 \mathrm{mg} \mathrm{L}^{-1}$ after the sedimentation pond; however, this water did not flow directly in the river but in the main ditch.

2. Concentration of phosphate ions in water is not close to the determination limits, $0.03 \mathrm{mg} \mathrm{L}^{-1}$ is the biggest value obtained in the study, and it is far from the limit value of the water quality standard (50 $\mathrm{mg} \mathrm{L}^{-1}$ ). Therefore, it is not necessary to collect data about phosphates in drainage systems dominating with mineral soils; however, it may be needed in drained areas dominated by organic soils.

3. Only concentration of total nitrogen has correlation with the amount of precipitation. As rainfall increased, the content of total nitrogen in water grew up and efficiency of sedimentation decreased. Still none of the ponds had exceeded limit values in the water quality standard. Concentration of nitrate ions had some correlation with precipitation only in the sedimentation pond 'Ilzites' N-120. This is probably because of the large basin of the drainage system and considerable share of peatlands; however, to prove this hypothesis additional studies need to be done.

4. In several objects it was found that the water inlet is too close to the sedimentation pond and river water came into the sedimentation pond and changed composition of sediments by additions from natural streams. This process could result in underestimation or overestimation of nutrient loads into water bodies.

5. In further studies, new water quality standards should be developed, which include total allowable pollutant output in grams in 24 hour cycles, because in some objects with larger drainage areas and bigger ditch system water flow rate is higher, thus increasing the total output of the polluting particles.

\section{Acknowledgements}

This study was supported by Latvian State Forest Research Institute 'Silava'.

\section{References}

1. Cabinet of Ministers of the Republic of Latvia. (2002). Cabinet Regulation No.118 Noteikumi par virszemes un pazemes ūdeṇu kvalitāti (Regulations Regarding the Quality of Surface Waters and Groundwaters). Retrieved March 2, 2018, from: https://likumi.lv/doc.php?id=60829\#piel1\&pd=1. (in Latvian).

2. Campanella, L., Cubadda, F., Sammartino, M., \& Saoncella, A. (2001). An algal biosensor for the monitoring of water toxicity in estuarine environments. Water Research, 35(1), 69-76. DOI: 10.1016/ s0043-1354(00)00223-2.

3. Joensuu, S. (1997). Factors affecting sediment accumulation in sedimentation ponds. Lewis Publishers, Boca Raton, FL. Retrieved January 9, 2018, from: https://books.google.lv/books?hl=lv\&lr=\&id=GpT6es kFUF8C\&oi=fnd\&pg=PA297\&dq=+Factors+affecting+sediment+accumulation+in+sedimentation + pond s.\&ots=ykEOLj2G-l\&sig=P0-qTzI-XLRX8u7xBecEiTP27VE\&redir_esc=y\#v=onepage\&q=Factors\%20 affecting\%20sediment\%20accumulation\%20in\%20sedimentation\%20ponds.\&f=false.

4. Joensuu, S.,Ahti, E., \& Vuollekoski, M. (1999). The effects of peatland forest ditch maintenance on suspended solids in runoff. Retrieved January 9, 2018, from: http://jukuri.luke.fi/bitstream/handle/10024/508094/ Joensuu.pdf?sequence $=1$. 
5. Kḷaviņš, M. (1996). Vides k̦īmija (Environmental chemistry) Riga: Latvian University (in Latvian).

6. Kløve, B. (2000). Retention of suspended solids and sediment bound nutrients from peat harvesting sites with peak runoff control, constructed floodplains and sedimentation ponds. Boreal Environment Research, 5(1), 81-94. Retrieved January 16, 2018, from: http://www.borenv.net/BER/pdfs/ber5/ber5081s.pdf.

7. Lībiete-Zālīte,Z. (2012). Atskaite par pētījuma Metodes un tehnologiijas meža kapitālvērtības palielināšanai virziena Mežsaimniecisko darbību ietekmes uz vidi un biologisko daudzveidību izpēte otrā etapa darba uzdevumu izpildi (Report on the study of the methodology and technology for increasing the value of forest. Investigation of the Impact of Forestry Activities on the Environment and Biodiversity on the Implementation of the Second Stage Tasks) Retrieved January 9, 2018, from: http:/www.lvm.lv/images/ lvm/Atskaite.pdf. (in Latvian).

8. Väänänen, R. (2008). Phosphorus retention in forest soils and the functioning of buffer zones used in forestry. Dissertationes Forestales. Retrieved January 16, 2018, from: http://www.metla.fi/dissertationes/ df60.pdf. 